\title{
Kuwaiti Parents' Perceptions towards Introducing a Foreign Culture into Their Children's EFL Textbooks in Public Elementary Schools
}

\author{
Mohammad Almutairi \\ Language Centre, College of Basic Education (CBE), Public Authority for Applied Education \& Training, Kuwait
}

\begin{abstract}
This study aims to investigate Kuwaiti parents' views and opinions towards introducing native speakers' and international cultures into their children's' EFL textbooks in public schools in the light of recent debates that discuss the relationship between culture and English language teaching. It also intends to explore and discover their perceptions towards the current cultural content being taught in Kuwait public elementary schools. For this purpose, questionnaires were distributed among Kuwaiti parents whom their children study in the government public schools followed by semi-structured interviews to get more detailed and in-depth information about the topic discussed. The findings of this study show that the vast majority had negative opinions and views towards exposing their children to native speaker's cultures for social and religious reasons. One of which is their underlying concern about the negative impacts of native speakers' content on their children's cultural and national identity. However, most of them agreed their children learn EFL through the prism of the international multicultural cultural content to prepare them use the language in different cultural contexts when they grow up. The results also showed that most of them preferred to keep the current ELT syllabus which uses the host cultural content rather than replacing it with the native speakers' one for the same reasons and also in view of growing awareness of the role played by culture in the EFL classroom which propound the nature of the Kuwaiti society of being conservative and cautious.
\end{abstract}

Index Terms — applied linguistics, EFL, ESL, language and culture, English language curriculum

\section{INTRODUCTION}

The English language is now widely spoken in most countries across the globe, and, hence, is often referred to as "Global Phenomenon", "World Englishes" or "Lingua Franca English". Although it is not the official language in most countries, it is taught as a foreign or a second language almost everywhere. According to Graddol (1997), English is no longer considered as the exclusive cultural property of the native speaking countries but as a language that is absorbing aspects of cultures worldwide as it continues to grow.

English is now indispensable in all transnational aspects of life including technology, commerce, telecommunications, medicine, pursuing higher academic achievements and obtaining better employment opportunities in addition to a very important way of communication across cultures in many countries and regions. As Devrim \& Bayyurt (2010) aptly articulate: "It is an undeniable fact that English has become a global lingua franca. It is the most commonly spoken foreign language, language of media, language of technology, and language of science” (p.4). However, there are some researchers such as Modiano (2001) who argue that the spread of the English language and its culture today is a kind of linguistic imperialism which we have to be vigilant against. Others like Cooke (1988) use the metaphor of the Trojan horse to describe the way that the English language and its culture may be welcomed at first in a country but after some time, cause fear once it begins to dominate the native language(s) and culture(s).

Some countries in the Middle East encourage the teaching of English as a second or foreign language through the prism of the buttressed host culture. It might be preliminarily proposed that because of cultural, religious or political reasons, a foreign language should best be taught and presented with minimal reference to Native Speakers' Cultures. For cultural reasons, some cultures might have their special traditions and habits, which are carefully guarded in the face of a perceived or real threat from outside. To protect the identity of their people, decision-makers might refuse some practices and perspectives presented in a range of foreign textbooks and other materials. For religious reasons too, some cultures might not share the same beliefs and behaviors such as male/female illegitimate relations, music, and mixed dancing, and co-education. To protect the beliefs of their people, some countries prefer to design their text and course books which represent the host nation's religious beliefs and practices. Similarly, for political reasons, some countries might consider the teaching of a foreign language as a kind of political imperialism, especially if it is the language of superpower (Shaw 1981).

\section{StATEMENT OF THE PRoblem}

Being a conservative country with strong traditional and religious values, Kuwait has structured the teaching and representation of English in the country public schools in conformity to the host culture and providing a conducive 
platform of practicality of the language being learnt. However, this has resulted over the years in a potentially negative outcome of denuding English of its international dimension, with unsatisfactory effects on learners' performance outside Kuwait.

Since one key role and function of English in Kuwait is to enhance capacity for international higher education and employment, this policy towards ELT in public schools in Kuwait in the current age of globalization needs to be addressed, deliberated and discussed further. This urgent concern has arisen in many significant discussions between parents, decision-makers who call for a re-evaluation of this policy (EFL education) and the need for changes, improvement or retention of the status quo.

\section{NATURE OF THE KUWAITI SOCIETY}

Because the nature of a country might determine what to be taught and not to be taught, the researcher believes that it is very important for the readers to understand the subtle nature of the Kuwaiti society from the inside to get a comprehensive understanding of the topic discussed.

Kuwait's population which is almost a million and a half makes it very unique. Some like Hajaj (1981) think it is a conservative society whereas others like Zughoul (2003) believe it is a religious one. As I am part of that society, I, in the fitness of things, would like to describe the way I live and this could give a clear idea about its nature. I live with my family which consists of six members, my wife, two sons, and two daughters and I. The house I live in is a two storey building that has a separate sitting room for men and another one for women. This is because men are not allowed to enter the house, instead, they go to their private room called "Dewaniya". They are also not allowed to see or to speak with my wife or my daughters unless they are very close relatives like uncles or aunts, grandfathers or grandmothers. My wife always wears long black cloth and a mask to cover her face. My daughters wear black Hijabs (hair cover) and long black clothes. Because girls and boys study in separate schools, my daughters study in the girls' schools in my area and when I go to pick them from there, there is always a police car to secure the place and to be sure that no boys or young men come and behave inappropriately, e.g. by flirting or dating. This does not mean that the society Kuwait is closed. In contrast, the free elected parliament and women's rights make Kuwait distinguished among its neighbors. Women play a very important role in Kuwait, there is one lady member in the parliament in addition to a minister in the government (minister of public works). In my opinion, the Kuwaiti culture contains both the religious and the conservative people as a majority and the liberal as a minority.

\section{PURPOSE OF THE STUDY}

The EFL learners have their own set of cultural experiences and objectives of using the target language by acquiring language proficiencies from the beginning to advanced levels through a gradual, step-by-step but effective approach. They have their own cultural amalgamation which has to be addressed during target language learning process to make it effective, meaningful and relevant to the learners. Despite this governing fact, the researcher puts forward his keen interest in developing and improving the ELT curriculum in Kuwait.

Primarily, it is to assume that integration of localised culture and contexts is inevitable while learning English as a foreign language. Against this backdrop, the results of this study might provide some insights and supportive information towards introducing foreign cultures (native or international) in public schools textbooks in the country. Decision-makers and EFL textbook designers in Kuwait might find this study and its conclusions a useful start towards evaluating and redefining the current EFL host curriculum in Kuwait putting into consideration issues like language and its relation with culture and its greatest role as an international language in the global world.

\section{RESEARCH QUESTIONS}

1) What are Kuwaiti parents' views and attitudes towards including Native Speakers' culture in their children's EFL textbooks in public schools?

2) What are Kuwaiti parents' views and attitudes towards including international cultures in their children's EFL textbooks in public schools?

3) What are Kuwaiti parents' views and attitudes towards the current host EFL curriculum taught to their children in public schools?

\section{LITERATURE REVIEW}

The researcher thinks it would be pertinent and adequate to define what culture is before going further in the study. In this regard, Nemni (1992) and Street (1993) believe that it is not easy to answer the question: What is the meaning of the word culture? Long-time ago, Kroeber and Kluckhohn (1954) discovered more than three hundred definitions of culture in their study, which in turn emphasize the difficulty of understanding the issues involved in culture and teaching about culture.

Among the various definitions of culture is the one developed by Spardley (1980) who defines culture as: 
Culture is comprised of three basic features of peoples' experience: what they do (cultural behavior), what they know (cultural knowledge), and what things they make and use (cultural artifact).

Studies on introducing foreign cultures into ESL and EFL classrooms and its connection with language have produced many different views and opinions of agreement and disagreement towards this hot and worth-pondering topic. Among the views supporting and rejecting which cultural content to be introduced in course books, this debate of the relation between language and culture is still unresolved and is still considered to be a conflict among researchers. Adaskou et al. (1990), for example, summarize the following arguments for having a foreign cultural content in EFL/ ESL course books:

1) It can promote international understanding.

2) It deepens an understanding of one's own culture.

3) It facilitates learners' visits to foreign countries.

4) It motivates EFL/ ESL learners to learn English.

There has been a shift toward the conception of 'culture' which is considered more open to the variety of cultures and social existence (Pieper 2016). Jenkins (2000) describes it as a phenomenon which has become the subject of considerable debate during the past few years.

This debate on the importance of English language and culture evolved about twenty years ago when different researchers from different countries have raised the question of "role and ownership of English language and its culture" in the globalized world or the "small village". It was only in the 1990's that the issue came to the surface with essays, surveys, books, and conferences trying to explain how it is that English can become truly a global language, what the consequences will be if it happens and why English became the main candidate for an international language (Crystal 2003). This resulted in different views and opinions among researchers which have created different schools of thought.

In this regard, here are two schools of thought regarding this issue; the first one is in favor of introducing native speakers' culture in EFL textbooks as it believes that the relation between the English language and its native-speaking culture is inseparable. Examples for supporters of this school are Seelye (1994), Byram and Fleming (1998), Bennet (1997) and Hendon (1980). The second school can be divided into 2a a group which supports the introducing of the host culture only; and $2 \mathrm{~b}$ which supports introducing of a range of representative cultures from around the world which would include both those of native speakers of English and of others where English is used as a second or foreign language. This latter school of thought with its two divisions opposes the first one and sometimes considers teaching native-speaking culture in English language education as a kind of linguistic or cultural imperialism. Those who hold the latter opinion are usually supporters of what is known at present English as an International Language (EIL) or the supporters of presenting the foreign language according to the host culture. Examples of supporters of this school are Alptekin (2002) \& (1993) and Modiano (2001).

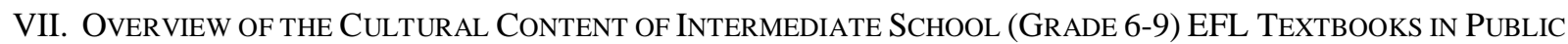 SCHOOLS With Special ReFerence To GRADE 7 TeXTbOOK}

The coursebook is called Target English by Keddle \& Hobbs (2008) and is designed to meet the needs of EFL learners at the intermediate school level in Kuwait. If we take the textbook of year 7, we find it consists of 6 units and are called (modules) in this textbook. Unit one titled My friend and I deals with the family life and relations in Kuwait in addition to discussing the favorite things of the Kuwaiti character Ahmad such as his mobile, his favorite Kuwaiti singer (Abdullah Ruwaished), chocolate, sports team, and other thing. On page 13 there is a small section called Reading and Speaking which has few lines about tradition houses in Kuwait. Module 2 School Days discusses Khalid's planning for the week, his activities, his painting training and his visits with his friend Jassim. The module also dwells on the safety in the science laboratory classes and precautions, what Khalid's mother say about him, the school circus and the map of the Kuwaiti place called Wattya. Module 3 Free Time Festivals presents the camping trip to the desert by Ahmad, Hassan, Salma, and Hiba with their parents Nawaf and Mariam. It also deals with the names of local Kuwaiti dishes and plates such as Hommous, Fattoush, Kebab and names of famous Kuwaiti restaurants such as The Garden Cafe in the capital. Module 3 also discusses the festival in Kuwait such as Eid Al-Fitr and also the Chinese New Year. There is a small paragraph about the famous Harrods and its history on Page 40. Module 4 Journey to the Past takes the EFL learners back to the history of science and almost turns to a science subject: translated to English. It begins with the history of the Arabic scientist Al-Idrisi and others; Leonardo Da Vinci and Brothers Wright. It also discusses the ways of spending holidays by some young Kuwaiti students named Rakan, Eman, Faris, Ali, Anwar, and Dalia. It continues dealing with spending holidays in the historic Jordanian city of Jerash. Module 5 World of Work begins with a discussion between a Kuwaiti father and his son rewarding him for his good behavior and reminding him about the good morals of the Kuwaiti society like honesty and helping other people. Then it goes to the weather condition in the country and the temperature of the neighboring gulf countries.

Except for a small amount of information about two Arab countries, the cultural content of the textbook Target English grade 7 seems to be nearly local. This is shown by the character names in the textbook which are all Kuwaiti names in addition to the activities done by the heroes like traveling and camping in the Kuwaiti desert. Also, mentioning the names of Kuwaiti restaurants, meals, and dishes seems to be very local. 


\section{METHODOLOGY}

To get answers for the four research questions, the researcher used the quantitative method and the qualitative method in his study as follows:

1) Quantitative method: Questionnaires were distributed to 100 Kuwaiti parents whom their children study EFL in public schools from different parts of the country to investigate:

a- Kuwaiti parents' views and opinions towards exposing their EFL children to native speakers' culture.

b- Kuwaiti parents' views and opinions towards exposing their EFL children to international culture.

c- Kuwaiti parents' views and opinions towards the current cultural content being taught to their EFL in schools.

2) Qualitative method: Semi-structured interviews for 5 parents were conducted to get more in-detailed information about the research questions and to give a chance for parents to add more contributions to the topics discussed.

In this regard, only 70 parents agreed to participate in the questionnaires. 5 parents only agreed to participate in the semi-structured interviews.

\section{Results \& DisCUSSIONS}

As mentioned earlier, this study aims to investigate Kuwaiti parents' views and attitudes towards including Native Speakers' international cultures in their EFL children's syllabus and their views and attitudes towards the current host EFL syllabus being taught to their children in public schools.

To get answers for such inquiries, a questionnaire was distributed for 80 parents from different parts of the country; 70 parents participated in the questionnaire and were asked to participate in a semi-structured interview; only 5 agreed to be interviewed.

The data collected from question 1 posit that the majority of parents (39:55.7\%) think that teaching English in isolation from its native culture doesn't affect negatively the process of EFL teaching in schools and doesn't create EFL underachievement(see diagram1). In contrast, the minority of parents (20:28.6\%) believe that teaching EFL without any reference to its native culture might have a negative impact on EFL learning. In regard of this point, one of the parents during his interview stated that the English language nowadays became a means of communication between different nations rather than a British or American belonging, for this reason, as he claimed speakers from different countries of the world no longer need native speakers' culture to communicate. Another participant said that he sees no contact between the teaching American daily practices or lifestyle and between failures in EFL learning.
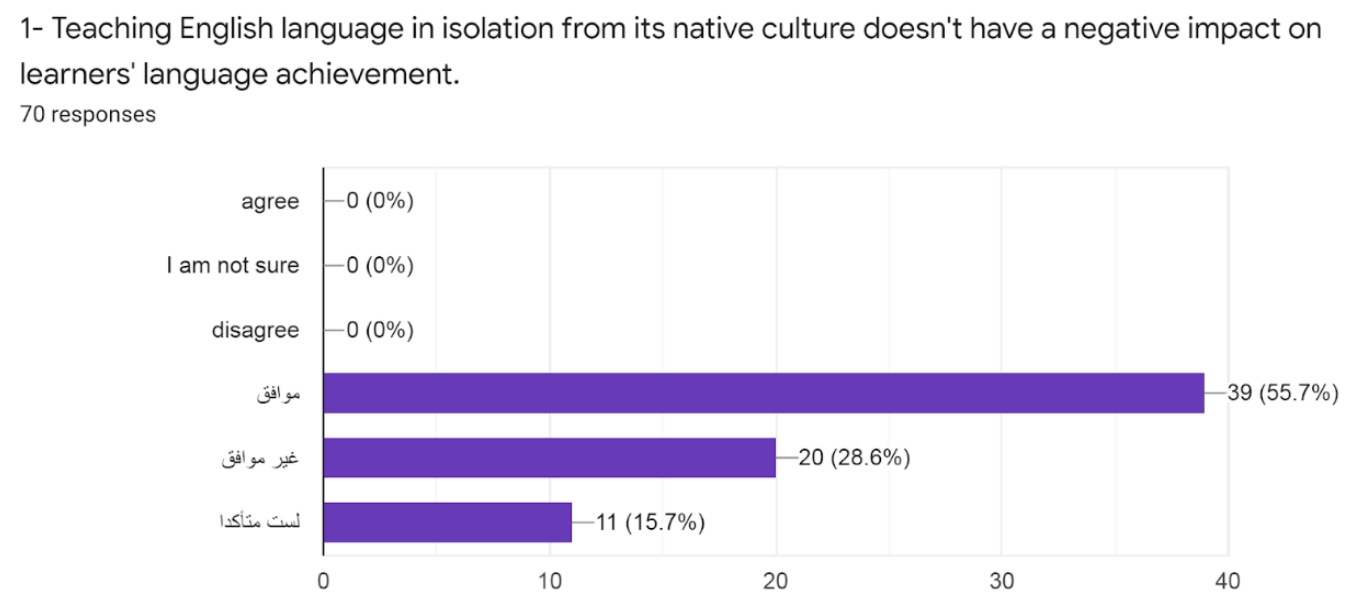

(diagram1)

As for question2 which tested the parents' opinion toward teaching EFL to their children through the prism of the native speakers' culture, the vast majority of participants $(41: 58.6 \%)$ were against this option (see diagram2). The participants who agreed did not even halve the ones who disagreed (20:28.6\%). The reasons behind parent's huge objection toward exposing their children to native speakers' culture could be associated with social or religious reasons.

As for the participants of this study, 4 of 5 interviewees informed the researcher that the reasons behind the disinclination of introducing native speakers' culture (American or British) in their children's EFL textbooks could be embedded to religious reasons. They think that learning Native speakers' culture can be a great threat to their children's Islamic beliefs and morals. One of the parents stated "I am not ready to see my children Americanized ". He continued to warn from a new kind of colonialism called "the cultural colonialism of the western countries" which could affect the Kuwaiti children's cultural beliefs. This could be very similar to what Modiano 22 (2001) calls " linguistic imperialism". 

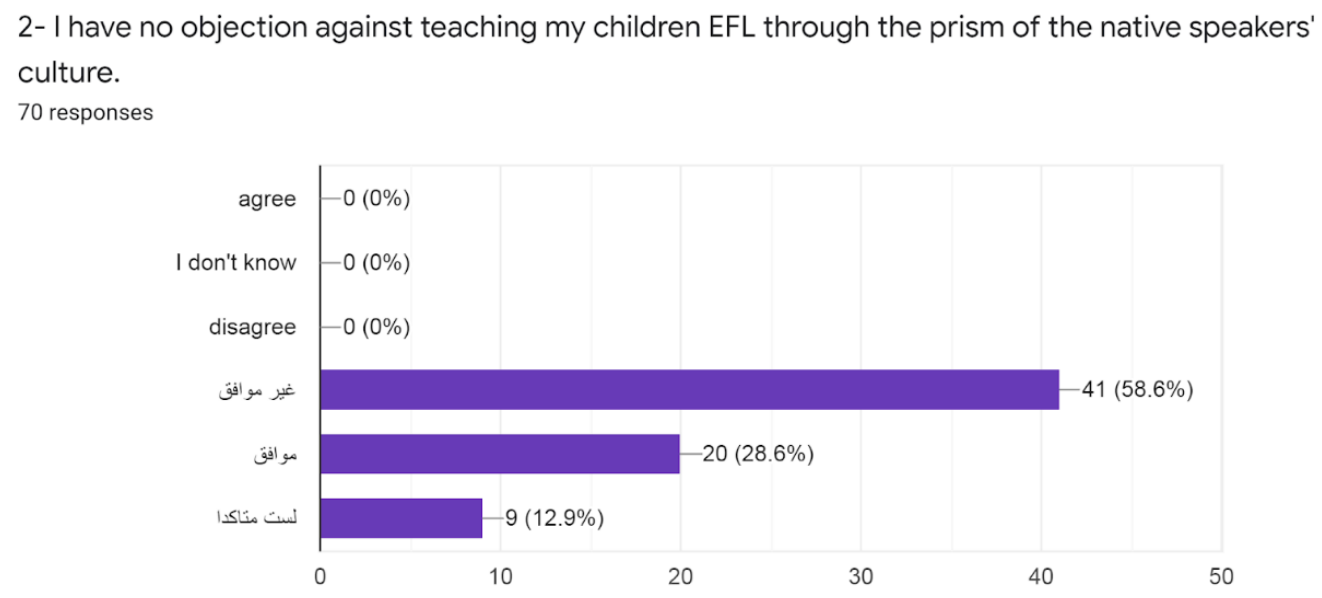

(diagram2)

Question3 was served to examine parents' opinions and views about the possibility of having a negative impact on their children's cultural or national identity when teaching EFL through the native speakers' culture. Again, the vast majority (49:70\%) believed that introducing native speakers' culture in EFL classrooms might have a negative impact on their children's cultural and national identity(see diagram3). They underpinned the focal point pertaining to maximizing and manipulating EFL learning to the high expectations in the propensity of localized contexts.

Only a few of them $(7: 10 \%)$ were against this belief. During the interviews with parents, two of them opined that they want their children to be like their fathers and to be patriotic and stick to their national identity. They want their boys to wear the Arabic uniform and not the jeans, to be far from illegitimate contact or relations with girls in the future and to be good Muslims. For this reason, as they proposed, they don't need their children to be exposed to American or British cultures that are widely deemed open, flexible and liberal in comparison.
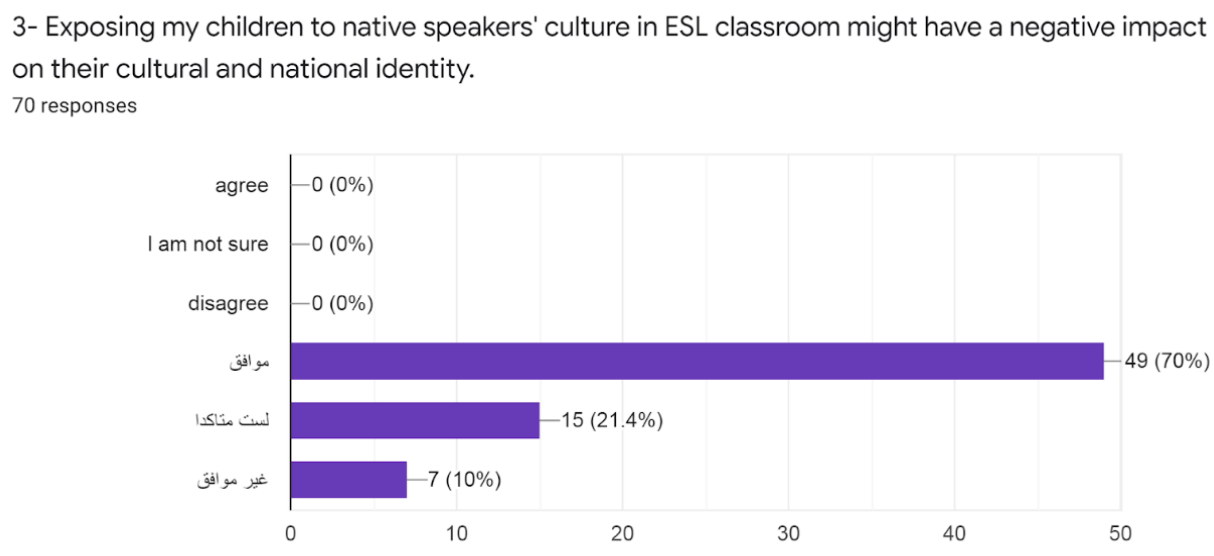

(diagram3)

Regarding question4 the data collated probed the parents' views and opinions about the possibility of having a social or a public opposition for any proposal for introducing American and British culture in EFL in public schools. Again, the responses indicated that the great majority of participants $(50: 71.4 \%)$ believed that the proposal would be faced by great opposition from the Kuwaiti society for religious and social reasons (see diagram4). One parent told the researcher while the interview a very interesting example of the sensitivity of the Kuwaiti society which happened before two decades. It started in 1998 when the Minister of Education proposed a plan to introduce teaching EFL (according to the host culture) but in grade 1 in public schools instead of grade 5. He added that the proposal created a big debate among the Kuwaiti society and the Minister was nearly lost his trust by the parliament. Only a few of the parents (7:10\%) agreed to expose their children to native speakers' culture. Their views could be justified in that some parents studied in the USA or the UK and liked the culture there. 


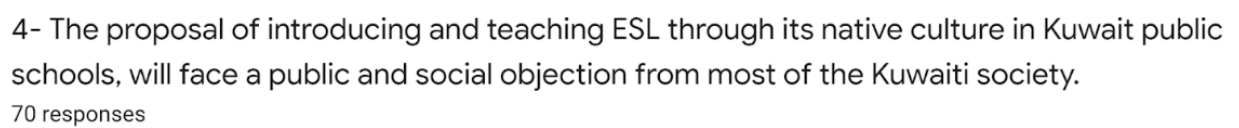
70 responses

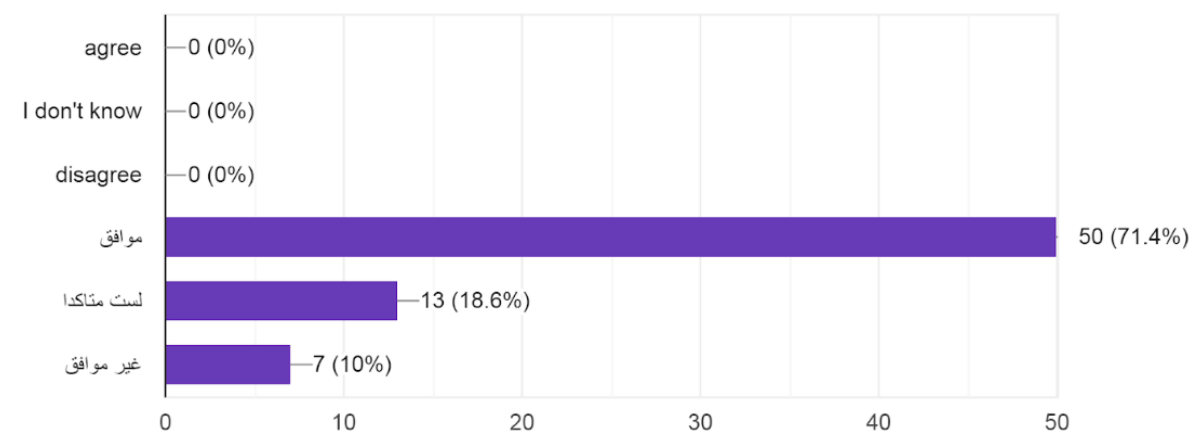

(diagram4)

Regarding question5 of the questionnaire which examined the parents' opinions and views about the impact of introducing native speakers' culture in EFL education on their children's lifestyle, the vast majority of the participants (46:65.7\%) agreed that it has a negative impact on their children's lifestyles (see diagram5). Only the (11:15\%) of them disagreed with this belief and did not think that exposing EFL children to native speakers' culture would result in a negative impact on their children's lifestyle.
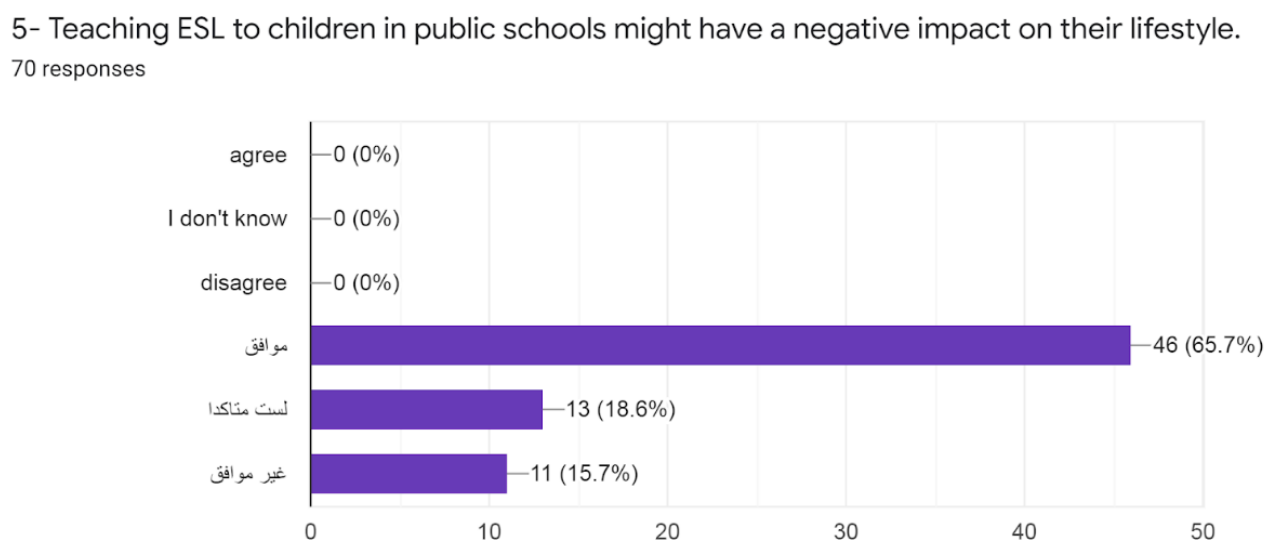

(diagram5)

In contrast to parents' views and opinions towards introducing the native speakers' culture to their EFL children in public schools, most of them in response to question 6 expressed their positive and encouraging attitudes towards teaching international (mixed) culture in their children's textbooks. The big majority of them (52:74.3\%) were in favor of teaching EFL through the prism of the international culture) whereas a little minority (7:10\%) refused that option (see diagram6). This inclination towards the international (mixed) culture and the disinclination towards the native speakers' culture could be justified by some parents' answers in the interview. One parent, for example, explained that the Kuwaiti society has red boundaries and considered to be one the most conservative societies in the middle east where alcoholic drinks are forbidden, discos do not exist, government segregated education is implied, the legitimate relationship between the two sexes is the only one allowed. This fact will accordingly lead people to refuse any American or British culture in ELT. He added that they instead could agree to use the international (mixed) cultures as an alternative because they are safer and controllable. A second parent explained that being in a global world where English is the main way of communication, international cultural content with careful selection could be a good choice for the EFL curriculum.

This inclination towards introducing the international (mixed) cultural content to EFL learners in public schools is obvious in the parents' responses in question8 and 9. 
6- I support teaching ESL in schools to my children through international mixed cultural content because it prepares them for using it in multicultural contexts in the future.

70 responses

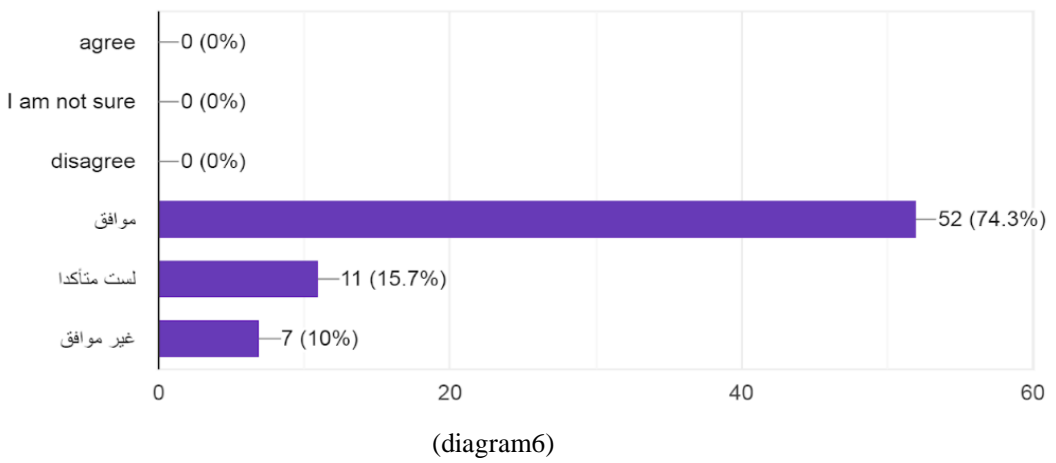

For question7, the vast majority of parents $(42: 60 \%)$ agreed that the option of introducing international cultural content to their children's EFL textbooks would not be faced by great opposition from the society. Only (12:17\%) disagreed (see diagram7).

\section{7- Teaching ESL through multicultural content will not be opposed by most of the Kuwaiti society. 70 responses}

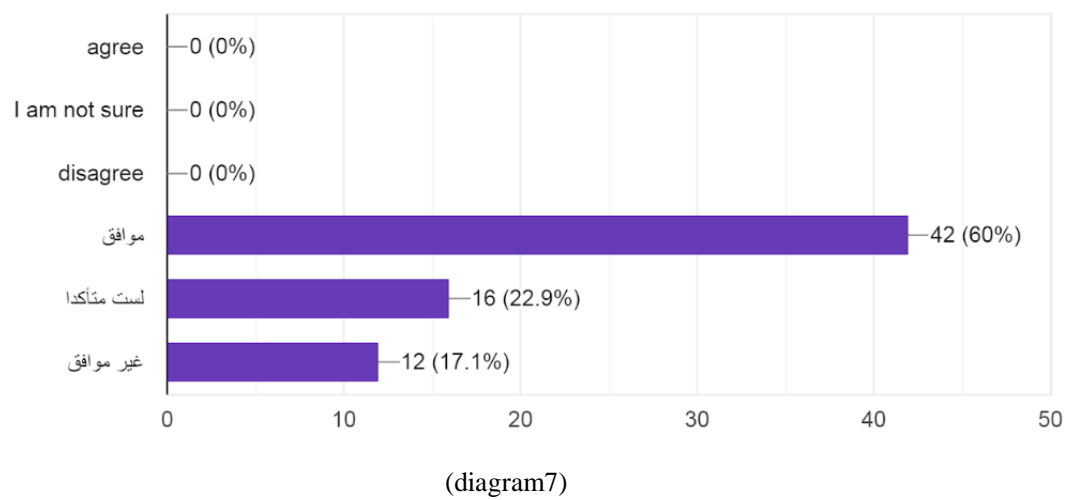

Again, in question8, the support for teaching English through the international (mixed) culture is very obvious. The great majority of parents (46:65\%)agreed that their children can be taught EFL through the prism of the international (mixed) culture due to globalization and the need for using English in different cultural contexts in the future when they grow up (see diagram8). only (14:65\%) disagreed with the question.

8- I support teaching EFL to my children through international multicultural content because I think it is safer and is the right option for the age of globalization.

70 responses

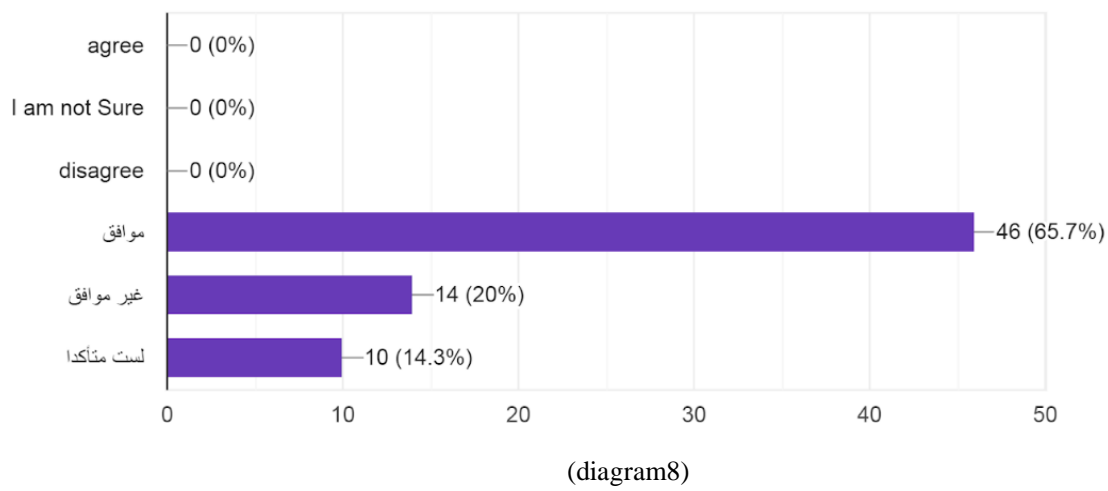

To examine the parents' attitudes towards the current cultural content being taught to their EFL children in public schools, question9 gave them the chance to choose between introducing the native speakers' culture and keeping the 
current EFL syllabus which is locally designed. The results were (36:51.4\%) of the parents preferred to keep the current syllabus rather than introducing English through the native speakers' culture (see diagrm9). (19:27\%) were against it. This could be evidence that the teaching EFL through the native speakers' culture is not welcome in the society in Kuwait.
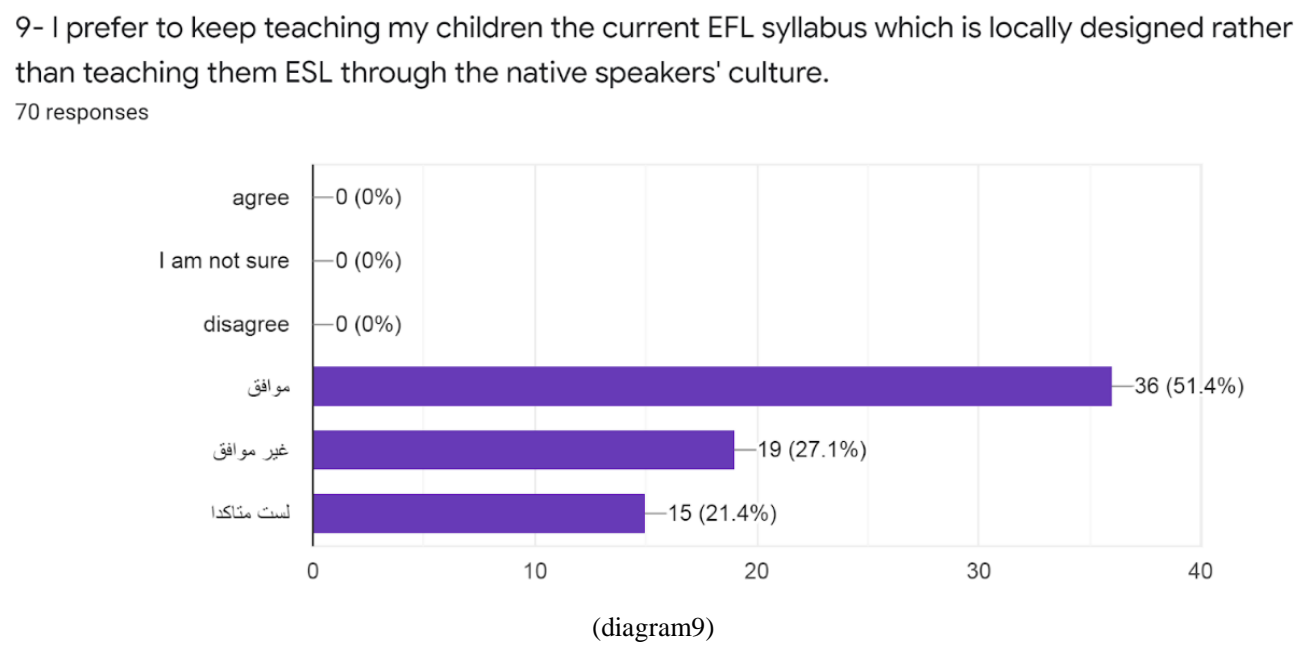

As we can notice from the parent's responses from the questionnaires and the interviews, the great and high percentages of parents' agreement were for:

9. a. teaching the international (mixed) cultural content to their EFL children as delineated in their answers for question6 (52:74.3\%).

9. b. keeping the same current host cultural as shown in their answers for question9 (36:51.4\%).

The great opposition was for introducing the American and British cultural component (native speakers' culture) as illustrated in the answer for question5 (46:65.7\%). This shows and proves that Kuwaiti parents are cautious in terms of dealing with foreign cultures in their children's EFL syllabus. We find them prefer to introduce their EFL children to international multicultural content as a first choice for improving their children's EFL learning in the global world or to keep the current curriculum rather than exposing them to native speakers' culture for social and religious reasons.

\section{Conclusions \& ReCOMmendations}

It is very obvious from the overview done by the researcher in number7 on elementary school textbooks particularly grade 7, that EFL is taught and presented to learners through the host culture with very few references to cultures from Arabic neighboring countries. One of the reasons for implementing this host and local cultural content could be religious or social including the public opinion of parents which could be an obstacle for developing a new syllabus for EFL learners in a conservative society like Kuwait.

However and due to the debates that English is now widely spoken by almost every country in the globe and some time is referred to as "lingua franca", the need for redefining the EFL syllabus in Kuwait elementary public schools is essentially warranted.

The findings of this study show that the views and opinions of parents towards introducing a multicultural international cultural content with careful selection in their children's textbooks are positive. For this reason, the researcher recommends that syllabus designers in the Ministry of Education in Kuwait should start necessary measures in line with practicality and utility of language learning to introduce new EFL syllabus in public schools which should entail careful and sagacious selection of multicultural content that is intended and envisaged to promote fruitful awareness of source culture, target culture and international culture and that, by stirring a curiosity for more knowledge and by offering a wide variety of informative themes, accommodate diverse learning and thinking styles, but certainly not at the cost of national and moral interests.

\section{APPENDIX}

\section{Interview questions:}

1- How many years have you been teaching EFL?

2- Could you tell about the cultural component of your textbooks?

3- Why do you think the reasons behind teaching EFL through the host cultural component in public schools?

4- What, in your opinion, are the advantages and disadvantages of using this sort of syllabus?

5- What, in your opinion, is the most suitable option to introduce EFL in the age of globalization? 
6- What's your opinion about exposing your children to native speakers' (American or British) culture in their EFL classrooms?

7- What do you think about teaching English through international multicultural content?

8 - If you have to choose between these 3 options, what would be your answer?

a- Teaching EFL in public schools through the native speakers' culture.

b- Teaching EFL in public schools through the international culture.

c- Teaching EFL in public schools through the host culture.

8- 8- If you have to choose between these 2 options, what would be your answer?

a- Teaching EFL in public schools through the native speakers' culture.

b- Keeping the current EFL syllabus in public schools which is designed through the host culture

9- Would you like add any comments regarding this issue?

\section{REFERENCES}

[1] Adaskou, K., Britten, D. and Fahsi, B. (1990). Design decisions on the cultural content of a secondary English course for Morocco. ELT, 44, 3-10.

[2] Alptekin, C. (1993). Target-language culture in EFL materials. ELT, 47, 136-143.

[3] Alptekin, C. (2002). Towards intercultural competence in ELT. ELT, 56, 57-64.

[4] Bennett, M. (1997). How Not to Be a Fluent Fool: Understanding the Cultural Dimension of Language. In A. Fantini, (Ed.). New Ways in Teaching Culture (p. 16-21). Alexandria, VA: TESOL Publications.

[5] Byram, M. \& Fleming, M. (1998). Language learning in intercultural perspective: Approaches through drama and ethnography. Cambridge, UK: Cambridge University Press.

[6] Cooke, D. (1988). Ties that Constrict: English as a Trojan Horse. In Cumming, A, Gagne, A. \& Dawson, J. (Eds.), Awareness (Ontario: TESL), 55-62.

[7] Crystal, D. (2003). English as a Global Language. Cambridge University Press.U.K.

[8] Devrim, D. \& Bayyurt, Y. (2010). Students' Understandings and Preferences of the Role and Place of "Culture "e in English Language Teaching: A Focus in an EFL context. TESOL, 2: 4-23.

[9] Graddol, D. (1997). The future of English: A guide to forecasting the popularity of the English language in the 21st century. London: British Council.

[10] Hajaj, S. (1981). English language teaching in Kuwait. Teaching English Abroad Newsletter. 12: $24-27$.

[11] Jenkins, J. (2000). The Phonology of English as an International Language. Oxford: Oxford U.P., 2000.

[12] Keddle, J., \& Hobbs, M. (2008). $3^{\text {rd }}$ edition. Target English Grade 7. Longman: UK.

[13] Kroeber, A., \& Kluckhohn, C. (1954). Culture: A critical review of concepts and definitions. New York: Random House.

[14] Modiano, M. (2001). Linguistic imperialism, cultural integrity and EIL. ELT, 55, 339-346.

[15] Nemni, M. (1992). Mefiez-vous du discours interculturel ! Canadian Modern Language Review, 49(1), 10-36.

[16] Seelye, H. (1994). Teaching culture: Strategies for intercultural communication (3rd Ed.). Lincolnwood, Ill: National Textbook Co.

[17] Pieper, I (2006). The Teaching of Literature: Preliminary Study. Strasbourg: Language Policy Division. Retrieved from www.coe.int/t/dgu/linguistic/source/Pieper. (accessed 20 September, 2019).

[18] Shaw, D. (1981). Asians students' attitudes towards English. In Smith, L. (ed), Readings in English as an international language (pp. 21-29). London, Pergamon Press.

[19] Spradley, J. P. (1980). Participant Observation. New York: Holt, Rinehart and Winston.

[20] Street, B. (1993). Culture is a verb: Anthropological aspects of language and cultural process. In D. Graddol, L. Thompson, \& M. Byram (Eds.), Language and culture (pp. 23-43). Clevedon, Avon: Multilingual Matters and BAAL.

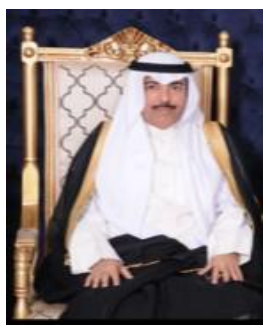

Mohammad Awad Almutairi is an assistant professor and the Head of English Language Unit, The Language Center, College of Basic Education, State of Kuwait. He has been involved in teaching EFL for college students since 1992 among different colleges: College of Business Studies, College of Technological Studies and finally College of Basic Education.

He has earned his BA in English Language\& Linguistics from Kuwait University in 1992, M.A. in Education (ELT) from the University of East Anglia, U.K. in 2003, and PhD in English Language and TESOL from the University of Leeds met in 2012. His main interests are Language \& Culture and TESOL. 